\title{
Comparative Study of Microwave Oven-Assisted Tissue- Processing with Isopropanol and Mineral Oil Mixture and Propylene Glycol Methyl Ether on Morphological Quality of Tissue Sections.
}

\author{
Sri Darsheny ${ }^{1}$, Saint Nway Aye ${ }^{2}$, Purushotham Krishnappa ${ }^{3}$, Rashindra Ravindran ${ }^{4}$ \\ ${ }^{1,2,3,4}$ Department of Pathology, School of Medicine, International Medical University, Malaysia
}

Meywords
Microwave oven, Tissue-processing, Xylene,
Isopropanol, Mineral oil.
Corresponding Author
Dr Purushotham Krishnappa
HOD- Pathology
International Medical University (IMU)
No.126, Jalan Jalil Perkasa 19, Bukit Jalil,
57000 Kuala Lumpur, Malaysia
Tel: 603-2731 7588.
Mobile: (+60) 146452300
Email: purushotham_krishnappa@imu.edu.my
Received: 6 July 2021; Accepted: 2 September
2021
Doi: https://doi.org/10.31436/imjm.v20i4
(a)

\begin{abstract}
INTRODUCTION: The prevalence of diabetes mellitus is increasing globally, despite the best current therapies available. A large diversity of animal models has been developed for a better understanding of the pathogenesis of diabetes mellitus. This study aimed to develop a rat model that mimics the metabolic characteristics of human type 2 diabetes mellitus. MATERIALS AND METHODS: Twenty-four male Sprague-Dawley rats (200-250 g) were divided into two groups and fed either a commercially available standard pellet $\operatorname{diet}(n=8)$ or a self-prepared high-fat diet (HFD) $(n=16)$ for 6 weeks. HFD-fed rats were significantly obese compared to standard-fed rats. Eight of the obese rats were injected a single low dose of streptozotocin (STZ) at $35 \mathrm{mg} / \mathrm{kg}$ intraperitoneally to induce type 2 diabetic rat (T2DR) and were monitored for 6 weeks. RESULTS: The weekly fasting blood glucose levels (FBG) in T2DR remained consistently high throughout the 6 weeks. The T2DR group exhibits decreased bodyweight, increased water intake, increased 24-hour urine volume with microalbuminuria, hyperlipidaemia, altered liver and kidney functions, and structural changes of the islet of Langerhans. CONCLUSIONS: This model simulates the natural disease progression and metabolic characteristics of type 2 diabetic patients. This model mimics the human syndrome that can be maintained at a reasonable cost and is easy to develop.
\end{abstract}

\section{INTRODUCTION}

Tissue-processing in histology is an important procedure that is routinely carried out in a histopathology laboratory. It is a crucial physical process that takes place after gross examination of tissue and in between tissue fixation and embedding to obtain thin sections of tissue for microscopic analysis. Dehydration, clearing and infiltration are the three predominant steps of tissue processing, which allows diffusion of various chemical solutions into the biological specimen. The conventional method of tissue processing in histology has been practised as the gold standard, but the overall turnaround time could take up to at least a day. Therefore, histological fixation using microwave energy has been tried as an alternative to the conventional technique. ${ }^{1}$ Microwave produces uniform heat thereby increasing the rate of tissue penetration of reagents and results in substantial reduction in the turnaround time to less than a day, permitting same day diagnosis for variety of tissue specimens. $^{2}$

Clearing is a crucial step in tissue processing which aims to efficiently remove alcohol and other dehydrating agents from tissue rendering it for paraffin infiltration. The most commonly used and preferred clearing agent by histologists is xylene due to its excellent compatibility with alcohol and paraffin wax. Xylene is a colourless, sweet- smelling, aromatic hydrocarbon in liquid or gas form that is naturally found in coal, petroleum and wood tar. ${ }^{3}$ Despite this, the main concern with xylene usage is its toxicity in which a long term exposure could be particularly injurious to health, especially to the histologists. ${ }^{4}$ It is widely recognised as a neurotoxin and can get stored in adipose tissue with a half-life of 1 to 6 days resulting in permanent disability in many workers. ${ }^{5}$

Considering the serious adverse effects of xylene, various xylene substitutes which are non-toxic and inexpensive have been tried as safer alternatives to spare the histologists from its occupational health hazards. Numerous xylene substitutes, such as n-heptane, isopropanol and mineral oil mixture and propylene glycol methyl ether (PGME) have been suggested as ideal alternatives to xylene in tissue-processing. The usage of mineral oil to replace xylene does not possess any health or environmental risks and is seen to have microtome 
advantages. ${ }^{6}$ PGME on the other hand, exhibits excellent solvent and coupling properties and is less toxic compared to xylene. ${ }^{7}$ This study focuses on evaluating the efficiency of isopropanol and mineral oil mixture and PGME as clearing agents in microwave-assisted tissue processing on the quality of staining such as cytoplasmic details, nuclear details and staining characteristics as compared with xylene-treated tissue.

\section{MATERIAL AND METHODS}

Tissue samples of skeletal muscles from 10 rat carcasses were obtained from the International Medical University (IMU) Animal House Facility. All the tissue samples were fixed in $10 \%$ buffered formalin for a minimum of 24 hours. The formalin was prepared in a ratio of 1:9 using 37\% formalin stock solution with ultrapure water. The tissue samples were examined and gross-sectioned into $2 \mathrm{~cm}$ blocks. A total of 60 tissue blocks were obtained, 20 representative blocks for xylene and each xylene substitute. The tissues were placed in individual tissue cassettes.

The prepared tissue samples were processed in a domestic microwave oven (Panasonic NN-SM33HM). Twenty specimens for each protocol were processed with microwave. The tissues were microwaved in microwave-resistant $500 \mathrm{~mL}$ beakers. For dehydration, a mixture of isopropyl alcohol and acetone (1:1) was used. The clearing step was done with the two xylene substitutes, namely the isopropanol/mineral oil mixture and PGME, followed by wax impregnation.

The temperature of the microwave was maintained between 50 to $65^{\circ} \mathrm{C}$, and after each step, the microwave was allowed to cool for 1 minute, before proceeding to the next step of the processing to avoid overheating of the solutions. The volumes of the reagents used were ensured adequate for complete immersion of the tissue cassettes. Fresh reagents were used at each step of the processing. The steps followed in tissue processing with each protocol are outlined in Figure 1. The processed tissues were embedded in paraffin using paraffinembedding model Leica RM2135. A total of 60 paraffinembedded tissue blocks for xylene and each xylene substitute were prepared. Sections of $4-5 \mu \mathrm{m}$ thickness were taken from each paraffin-embedded tissue block using Leica rotary microtome. The ribbons were floated on a water bath at $50^{\circ} \mathrm{C}$ before mounting on microscopic slides. The sections were allowed to attach on the slides on a hotplate at $60^{\circ} \mathrm{C}$.

The sections were stained manually with Haematoxylin and Eosin. The haematoxylin and eosin (H\&E) stained sections were evaluated by an experienced pathologist under 10x and 40x magnification using Nikon Ni-U microscope without any knowledge of the xylene substitutes used in the processing technique. The qualities of the slides were assessed, based on IMJM Volume 20 No.4, October 2021
3 morphological parameters: the cytoplasmic details, the nuclear details and the staining characteristics, which has been presented in Table 1. The scores which were assigned by the evaluator after the microscopic examination of the slides were as follows: Score 2 (Good) if two or three parameters were satisfied, Score 1 (Fair) if one or two parameters were satisfactory and Score 0 (Poor) if none of the parameters were satisfactory.

Table 1: Qualitative morphological analysis by using light microscopy

\begin{tabular}{|c|c|c|}
\hline Parameters & Features & Quality of slides \\
\hline Cytoplasm & $\begin{array}{l}\text { Eosinophilia of cytoplasm; } \\
\text { Nuclear -cytoplasmic contrast }\end{array}$ & $\begin{array}{l}\text { Unsatisfactory }=0 \\
\text { Satisfactory }=1 \\
\text { Good }=2\end{array}$ \\
\hline Nucleus & $\begin{array}{l}\text { Chromatin condensation; } \\
\text { Nuclear membrane; Mitotic } \\
\text { figures }\end{array}$ & $\begin{array}{l}\text { Unsatisfactory }=0 \\
\text { Satisfactory }=1 \\
\text { Good }=2\end{array}$ \\
\hline $\begin{array}{l}\text { Staining } \\
\text { characteristics }\end{array}$ & $\begin{array}{l}\text { Eosinophilic cytoplasm, Crisp } \\
\text { Staining of nucleus, Nuclear } \\
\text { cytoplasmic contrast }\end{array}$ & $\begin{array}{l}\text { Unsatisfactory }=0 \\
\text { Satisfactory }=1 \\
\text { Good }=2\end{array}$ \\
\hline
\end{tabular}

\section{RESULTS}

A total of 60 samples were prepared, which were subsequently divided into three groups for xylene, isopropanol with mineral oil mixture and propylene glycol methyl ether (PGME) with 20 samples each. However, the number of slides obtained for isopropanol and mineral oil mixture and PGME were 7 each and 8 for xylene. During microtome sectioning, most of the embedded tissue breaks to small pieces and could not secure the ribbons of section to do proper H\&E staining and some tissues were lost in water bath.

The scores which ranged from 0 to 2 were assigned to each of the slides upon evaluation by a pathologist based on the three parameters and are tabulated in Tables 2 and 3. The outcome for tissue processed with isopropanol and mineral oil mixture was 28.6\% unsatisfactory, 28.6\% satisfactory and $42.8 \%$ good sections. In PGME-treated tissues, 14.3\% were unsatisfactory sections, $71.4 \%$ were satisfactory and $14.3 \%$ produced good quality sections.

Sections from the skeletal muscle tissue processed with xylene clearly showed the morphological characteristics of the cells.

Table 2: Overall score percentage of tissues processed with xylene isopropanol/ mineral oil mixture and PGME.

\begin{tabular}{|c|c|c|c|c|}
\hline Slides Scores & $\begin{array}{l}\text { Unsatisfactory } \\
(\text { Score } 0)\end{array}$ & $\begin{array}{l}\text { Satisfactory } \\
\text { (Score 1) }\end{array}$ & $\begin{array}{l}\text { Good } \\
\text { (Score 2) }\end{array}$ & $\begin{array}{l}\text { Good } \\
\text { (Score 2) }\end{array}$ \\
\hline $\begin{array}{l}\text { A (Xylene) } \\
\text { (Control) }\end{array}$ & $0 \%$ & $0 \%$ & $0 \%$ & $100 \%$ \\
\hline $\begin{array}{l}\text { B (Isopropanol + } \\
\text { Mineral oil) }\end{array}$ & $28.6 \%$ & $28.6 \%$ & $28.6 \%$ & $42.8 \%$ \\
\hline C (PGME) & $14.3 \%$ & $71.4 \%$ & $71.4 \%$ & $14.3 \%$ \\
\hline
\end{tabular}




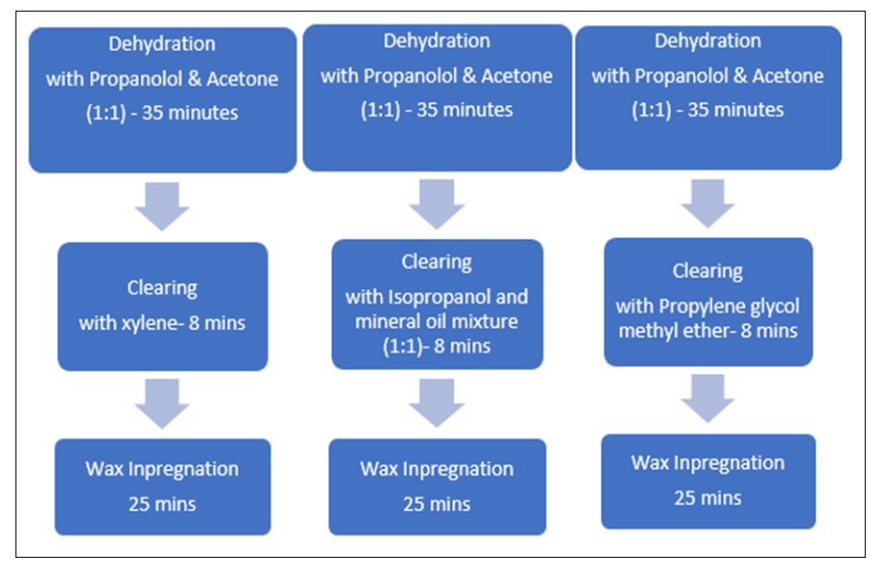

Figure 1. Flow chart for microwave tissue processing with xylene, Isopropanol with mineral oil mixture and Propylene glycol methyl ether (PGME).

The staining was smooth and adequate to identify the different components of the cells like cell membrane, cytoplasm, nucleus etc (Figure 2). All the sections treated with xylene showed the consistent staining quality and were used as the control slides in comparison to the quality of the slides of other two groups. Majority of the sections (85\%) of skeletal muscle tissue processed with PGME belonged either to good or satisfactory category. The staining quality of these slides were adequate to identify the various components of the tissue and cells (Figure 3). Around 70\% of the sections of skeletal muscle tissue processed with isopropanol mixed with mineral oil showed good/ satisfactory morphological and staining quality of the tissues which were comparable to the quality of the sections from samples treated with PGME (Figure 4).

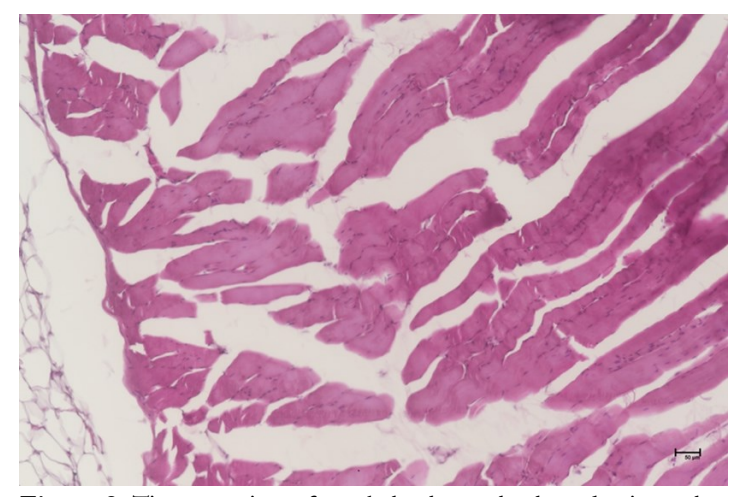

Figure 2: Tissue section of rat skeletal muscle cleared using xylene and stained with $\mathrm{H} \& \mathrm{E}$ staining at $10 \mathrm{x}$ magnification.

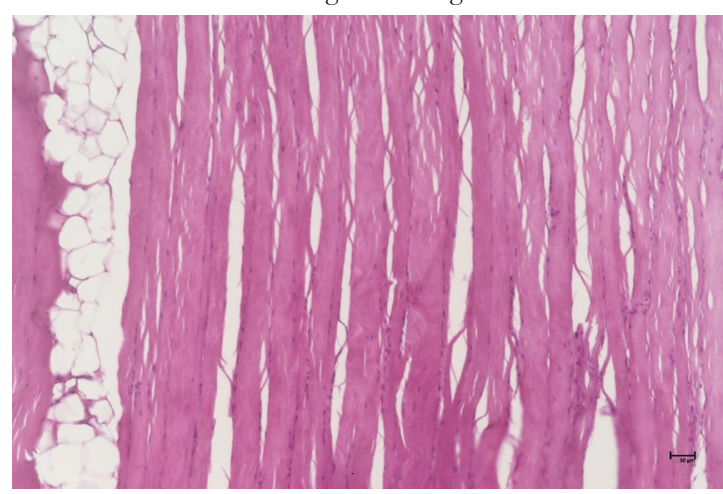

Figure 3: Tissue section of rat skeletal muscle cleared using PGME and stained with H\&E staining at $10 \mathrm{x}$ magnification.

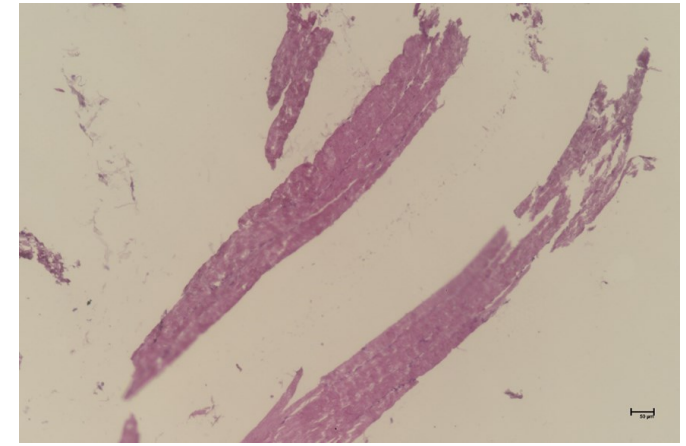

Figure 4: Section of rat skeletal muscle cleared using isopropanol/ mineral oil mixture and stained with $H \& E$ at $10 x$ magnification .

\section{DISCUSSION}

The most common method for preparing tissues for microscopy consists of preserving the tissue by formalin fixation, followed by dehydration, clearing, paraffin wax embedding, sectioning and staining. Xylene is the most widely used solvent in most of these procedures. However, exposure through inhalation, accidental ingestion, skin and eye contact can cause debilitating effects on nervous system, blood, liver, kidneys and eyes in long term exposure. ${ }^{8}$ Therefore, a non-toxic substitute with properties equal to or better than xylene would be excellent for personnel performing histochemistry on a regular basis. Thus far, various alternatives, namely limonene solvents, aliphatic hydrocarbons, aromatic hydrocarbons and vegetable oils were utilised in a histopathology laboratory. ${ }^{9}$

Mineral oil is an odourless liquid which is not as harmful and toxic as xylene. It is a non-polar reagent which allows elimination of fats from tissue by displacement, rather than by dissolution as xylene does. ${ }^{6}$ The mixture of mineral oil with isopropanol not only acts as a gentle clearing agent but also ensures complete dehydration of tissues. The isopropanol added into the mixture serves to reduce the viscosity of mineral oil facilitating the penetration of agent into the tissue. In a study conducted by Buesa et al. (2009), it is evident that clearing tissues with an isopropanol mineral oil alcoholic mixture followed by undiluted mineral oil alcoholic mixture is superior to using limonene reagents, alkanes or isopropanol by itself, constituting the safest and cheapest xylene alternative for clearing tissue without any adverse effects to personnel or tissues. ${ }^{5}$ In another study, Buesa et al. (2000) demonstrated that mineral oil was used to process tissues of different types and it was observed that mineral oil-processed tissue showed equivalent qualities when compared to xylene-processed tissue. $^{6}$

Other than mineral oil, the use of PGME as a xylene substitute has also shown to be an effective clearing agent in tissue processing. The lack of significant health effects 
Table 3: Score percentage for each parameter of tissue-processing with different clearing agent

\begin{tabular}{|c|c|c|c|c|c|c|c|c|c|}
\hline \multirow[b]{2}{*}{ Slides } & \multicolumn{3}{|c|}{$\begin{array}{l}\text { [Eosinophilia of cytoplasm; Nuclear - } \\
\text { cytoplasmic contrast] }\end{array}$} & \multicolumn{3}{|c|}{ [Chromatin condensation; Nuclear membrane] } & \multicolumn{3}{|c|}{$\begin{array}{l}\text { [Eosinophilic cytoplasm, Crisp Staining of } \\
\text { nucleus, Nuclear cytoplasmic contrast] }\end{array}$} \\
\hline & $\begin{array}{c}\text { Unsatisfactory } \\
\text { (Score } 0)\end{array}$ & $\begin{array}{l}\text { Satisfactory } \\
\text { (Score 1) }\end{array}$ & $\begin{array}{c}\text { Good } \\
(\text { Score } 2)\end{array}$ & $\begin{array}{l}\text { Unsatisfactory } \\
\text { (Score } 0)\end{array}$ & $\begin{array}{l}\text { Satisfactory } \\
\text { (Score 1) }\end{array}$ & $\begin{array}{c}\text { Good } \\
\text { (Score 2) }\end{array}$ & $\begin{array}{c}\text { Unsatisfactory } \\
\text { (Score } 0)\end{array}$ & $\begin{array}{l}\text { Satisfactory } \\
\text { (Score 1) }\end{array}$ & $\begin{array}{c}\text { Good } \\
\text { (Score 2) }\end{array}$ \\
\hline $\begin{array}{l}\text { A (Xylene) } \\
\text { (Control) }\end{array}$ & $0 \%$ & $0 \%$ & $100 \%$ & $0 \%$ & $0 \%$ & $100 \%$ & $0 \%$ & $0 \%$ & $100 \%$ \\
\hline $\begin{array}{l}\text { B (Isopropanol + } \\
\text { Mineral oil) }\end{array}$ & $28.6 \%$ & $28.6 \%$ & $42.8 \%$ & $28.6 \%$ & $28.6 \%$ & $42.8 \%$ & $28.6 \%$ & $28.6 \%$ & $42.8 \%$ \\
\hline (PGME) & $14.3 \%$ & $71.4 \%$ & $14.3 \%$ & $14.3 \%$ & $71.4 \%$ & $14.3 \%$ & $14.3 \%$ & $71.4 \%$ & $14.3 \%$ \\
\hline
\end{tabular}

possessed by PGME products are supported by the toxicity database. ${ }^{10}$ In 2010, Chen et al. used PGME to substitute for xylene and it was observed that PGME-treated tissues did not undergo shrinkage when compared to those treated with xylene. PGME-treated tissues exhibited less organic solvency than xylene and the overall excellent quality of H\&E staining was seen. The tissues were seen to retain elasticity without noticeable hardening or any changes to tissue dimension. Overall, it was seen that PGME provided greater tissue clarity and nuclear detail, conserved tissue antigenicity and was compatible with resinous mounting media. Their studies also confirmed that PGME is a novel xylene substitute for use in histopathological laboratory and for histochemistry applications. ${ }^{7}$

There are relatively fewer studies performed using isopropanol and mineral oil mixture and PGME as xylene substitutes in microwave-assisted tissue-processing as compared to the conventional method. In a study conducted by Patil et al. (2014), it was observed that the microwaveprocessed tissues yielded satisfactory morphological quality of tissue, being identical to those sections processed by conventional method in terms of tissue architecture, nuclear details, cytoplasmic details and the staining quality.

There were several limitations in our study. The first limitation is the microwave oven used for tissue processing was a domestic microwave oven (Panasonic NN-SM33HM) that did not have temperature control. Our study required the tissue processing to be done in a controlled temperature of 50 to $65^{\circ} \mathrm{C}$. However, the domestic oven provided for usage could only be adjusted to low, medium, medium high and high. Therefore, the exact temperature required for the processing could not be set resulting in fluctuations in temperature. To overcome this problem, we had to remove the beaker from the oven at intervals during each step of the protocol to prevent overheating and the temperature was made sure to range between 50 to $65^{\circ} \mathrm{C}$ with the aid of a thermometer. The second limitation to our study was difficulties in sectioning the tissue blocks to obtain proper thin sections of tissues. The issue with temperature control could have given rise to non-uniform heat distribution for adequate penetration of the reagents into the tissues. Therefore, the tissue could have not been cleared adequately to allow complete infiltration of paraffin wax into the tissues. Thus, the sections obtained were mostly broken into pieces and appeared in powdered forms due to incomplete clearing and incomplete paraffin wax infiltration during the tissueprocessing stage. As a result, the number of slides prepared were reduced to only 7 for each of the substitutes. All these limitations can be mitigated by more number of samples and a professional microwave which can control temperature accurately.

\section{CONCLUSION}

According to our results, isopropanol and mineral oil mixture and PGME can be suggested as alternative clearing agents to xylene, provided having access to a more sophisticated microwave oven with a precise temperature control for complete tissue-processing. In general, both the substitutes used to process the tissues were seen to have produced sufficient clarity of staining without severely compromising the structure of nucleus, cytoplasm and the staining characteristics. They also have the added advantage of being non-toxic and less harmful compared to xylene. However, further studies with larger sample sizes, more parameters and a more sophisticated microwave oven should be used to validate better results.

\section{List of Abbreviations}

PGME: Propylene glycol methyl ether

H\&E: Haematoxylin and Eosin

\section{DECLARATION}

Ethics approval: The study was approved by the International medical university joint committee of research and ethics (IMU-JC). 


\section{REFERENCES}

1. Mathai A, Naik R, Pai M, Rai S, Baliga P. Microwave histoprocessing versus conventional histoprocessing. Indian J Pathol Microbiol. 2008 Jan 1;51(1):12-6.

2. Thirumal Raj A, Patil S, Rao RS. A comparison of conventional and microwave decalcification and processing of tooth and mandibular bone specimens. J Clin Diagnostic Res. 2016;10(10):ZC121-6.

3. Metgud R, Astekar MS, Soni A, Naik S, Vanishree M. Conventional xylene and xylene-free methods for routine histopathological preparation of tissue sections. Biotech Histochem. 2013;88(5):235-41.

4. Alwahaibi N, Aljaradi S, Alazri H. Alternative to xylene as a clearing agent in histopathology. J Lab Physicians. 2018;10(2):189-93.

5. Rene J Buesa, Peshkov M V. Histology without xylene. Ann Diagn Pathol. 2009;13(4):246-56.

6. Rene J. Buesa. Mineral Oil: The Best Xylene Substitute for Tissue Processing Yet?, Journal of Histotechnology.2000; 23(2):143-149.

7. Chen CY, He T, Mao XL, Friis TE, Qin RH, Jian YT. A novel xylene substitute for histotechnology and histochemistry. Biotech Histochem. 2010;85(4):231-40.

8. Kandyala R, Raghavendra SP, Rajasekharan S. Xylene: An overview of its health hazards and preventive measures. J Oral Maxillofac Pathol. 2010;14(1):1.

9. Indu S, Ramesh V, Indu PC, Prashad K V., Premalatha B, Ramadoss K. Comparative efficacy of cedarwood oil and xylene in hematoxylin and eosin staining procedures: An experimental study. J Nat Sci Biol Med. 2014;5(2):284-7.

10. Spencer PJ. New toxicity data for the propylene glycol ethers - A commitment to public health and safety. Toxicol Lett. 2005;156(1 SPEC. ISS.):181-8. 